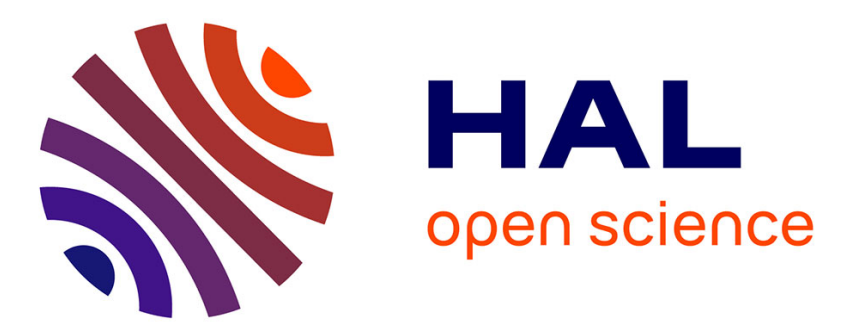

\title{
Annals of Forest Science changes its scope and complies with green open access rules
}

Erwin Dreyer, Marianne Peiffer, Jean-Daniel Bontemps, Jean-Michel Leban

\section{To cite this version:}

Erwin Dreyer, Marianne Peiffer, Jean-Daniel Bontemps, Jean-Michel Leban. Annals of Forest Science changes its scope and complies with green open access rules. Annals of Forest Science, 2014, 71 (4), pp.425-426. 10.1007/s13595-014-0370-8 . hal-01101749

\author{
HAL Id: hal-01101749 \\ https://hal.science/hal-01101749
}

Submitted on 9 Jan 2015

HAL is a multi-disciplinary open access archive for the deposit and dissemination of scientific research documents, whether they are published or not. The documents may come from teaching and research institutions in France or abroad, or from public or private research centers.
L'archive ouverte pluridisciplinaire HAL, est destinée au dépôt et à la diffusion de documents scientifiques de niveau recherche, publiés ou non, émanant des établissements d'enseignement et de recherche français ou étrangers, des laboratoires publics ou privés.

$$
\text { Copyright }
$$




\title{
Annals of Forest Science changes its scope and complies with green open access rules
}

\author{
Erwin Dreyer • Marianne Peiffer • \\ Jean-Daniel Bontemps • Jean-Michel Leban
}

Received: 3 March 2014 / Accepted: 11 March 2014 / Published online: 8 April 2014

(C) INRA and Springer-Verlag France 2014

The landscape for science editing in general, and particularly in the field of forest sciences, is changing at an accelerating pace. The Internet provides a huge number of new opportunities for disseminating scientific knowledge under diverse forms like databases, videos, short papers, additional material. There are many concerns in the scientific community about open access to research results. The European Commission for instance now requires that results produced with the financial support of European programs in the framework of Horizon 2020 should be published under an open-access scheme, unless there is a specific reason not to make them openly available (in the case of a "hot" innovation for instance).

Another concern arises from the observation that while the journals devoted to forest sciences (i.e., with "forest" or

\section{Handling Editor: Marianne Peiffer/Erwin Dreyer}

Contribution of co-authors All authors participated to the writing of this editorial.

E. Dreyer $\cdot$ M. Peiffer $\cdot$ J.-D. Bontemps $\cdot$ J.-M. Leban

"Editorial office of Annals of Forest Science", Centre Inra de

Nancy-Lorraine, F54280 Champenoux, France

E. Dreyer

Inra, UMR 1137 "Ecologie et Ecophysiologie Forestières",

F54280 Champenoux, France

\section{E. Dreyer $(\bowtie)$}

Université de Lorraine, UMR 1137 "Ecologie et Ecophysiologie

Forestières" Faculté des Sciences et techniques,

F54500 Vandoeuvre, France

e-mail: dreyer@nancy.inra.fr

\section{J.-D. Bontemps}

AgroParisTech, UMR 1092 “Laboratoire d'Etude de la Ressource Forêt-Bois", LERFoB, 14 rue Girardet,

F54000 Nancy, France

J.-D. Bontemps

Inra, UMR 1092, LERFoB, F54280 Champenoux, France "forestry" in their title) published a majority of the papers devoted to forests up to the 1990 s, this is no longer the case. A recent bibliometric survey covering the years 2002-2012 revealed that less than $10 \%$ of the papers dealing with some aspect of forests and forestry were actually published in journals devoted to the forest science area (unpub.). This shows the vitality of research activities on forests and the fact that forests are a wonderful field of investigation for ecologists, economists, biologists, engineers, computation scientists, biometricians, etc. worth publishing in the best disciplinary journals. It also poses the difficult question of what are the actual added value and the specificity of journals devoted to forests and forestry as compared to more specialized journals in ecology, genetics, wood sciences, etc.

For these reasons, Annals of Forest Science decided to change several aspects of its editorial policy.

Annals of Forest Science now fully complies with the requirements of green open access. All papers published in Annals of Forest Science are now made freely available under the publisher's version in an open repository (the French repository HAL) after the binding 12-month embargo which was agreed upon with our publisher Springer. To visit the repository, please go to http://hal.archives-ouvertes.fr/ ARINRA-AFS/fr. The deposit is done under the responsibility of the editorial board of the journal: authors are indeed still free to deposit the published versions of their papers in any institutional repository after the 12-month embargo. Moreover, authors are free to deposit the preprint and postprint versions of their manuscript in any institutional repository of their choice, provided they link the deposit to the published version on the journal's website (http://www. springer.com/life+sciences/forestry/journal/13595). This corresponds perfectly with the criteria of green open access, and we are very happy to announce this evolution in our editorial policy. We keep anyway our peer review system to check for the scientific quality of the papers we publish. By no 
way will we enter the race for publishing that leads currently to severe problems in science editing (Bohannon 2013).

A second and probably even more important change is the definition of a new scope for the journal. Forest ecosystems undergo really rapid changes under human and climatic pressures, whose consequences sometimes transcend the time of human perception. The forest and wood industries also undergo very rapid mutations and face many new challenges. Therefore, we need more multidisciplinary research aiming at understanding the processes driving these changes and their impact, as well as at suggesting measures to adapt forests and forestry to the ongoing and expected changes. The new scope therefore covers the following aspects:

(a) Biology of trees and associated organisms (symbionts, pathogens, pests)

(b) Forest dynamics and ecosystem processes under environmental or management drivers (ecology, genetics)

(c) Risks and disturbances affecting forest ecosystems: biology, ecology, and economics

(d) Forestry wood chain including tree breeding, forest management and productivity, ecosystem services, silviculture, and plantation management;

(e) Wood sciences, with an emphasis on the relationships between wood structure and tree functioning, and between forest management or environment and wood properties

Moreover, the editorial board encourages the following:

1. Review articles on timely topics in the scope of the journal

2. Multidisciplinary studies that address large forest areas and/or time spans

3. New ideas or methods for measuring or monitoring any property of interest for tree biology, forest ecosystem dynamics, and wood

4. Model-based papers focused on the forestry wood chain, including carbon accounting investigations, ecosystem services, and quantification of the relationships between forest management and the properties of end products

5. Papers addressing economic and social issues of forest management under climate change

6. Extended databases made available to a wider community

This new scope is now available in the instructions to authors that may be downloaded from the journal's website at http://www.springer.com/life+sciences/forestry/journal/ 13595?detailsPage= press.
Last but not least, we are also pleased to open a new section in the journal, devoted to papers presenting ecological databases. We will specifically address this issue in a forthcoming editorial, given its importance for the journal and for our scientific community.

Annals of Forest Science wishes to be a medium for scientific debates around hot issues in forest and wood sciences, and there are many. We therefore call for opinion papers dealing with issues felt important for the forest science. For instance, we recently published an opinion paper that was devoted to a fiery debate among scientists dealing with hydraulics in trees: what trust can we have in the published data of vulnerability to cavitation in the hydraulic conduits of trees (Cochard and Delzon 2013)? We also welcome any suggestion for submitting a review paper on any topic of interest with respect to the scope of the journal, as well as for launching a thematic issue on a specific topic; we already have a number of such issues in preparation dealing with very diverse topics like the use of allometric procedures to obtain reliable estimates of standing biomass in crowns, the impact of climate on tree growth, etc.

Annals of Forest Science is also aware that the impact factor of a journal should not be misused as it sometimes is. We signed the San Francisco Declaration on Research Assessment (DORA, http://am.ascb.org/dora/) which basically states that science assessment cannot base on the IF of journals in which results are published. The impact factor is by far not the best metric to measure the actual impact of a journal, and only a combination of several indexes may provide a somewhat less biased metric.

There are many other changes, and many to come. They are meant to develop Annals of Forest Science as an attractive journal for authors who wish to publish their results and ideas about forest and wood sciences. The editorial board of Annals of Forest Science will keep you informed of ongoing evolutions and hopes to contribute efficiently to the dissemination of relevant, important, and high-quality research results.

\section{References}

Bohannon J 2013. Who's afraid of peer review. Science 342: 60-65. www.sciencemag.org/content/342/6154/60.full.

Cochard H, Delzon S (2013) Opinion paper: Hydraulic failure and repair are not routine in trees. Ann For Sci 70:659-661. doi:10.1007/ s13595-013-0317-5 